\title{
Influence of shade and number of boulder layers on mobile organisms on a warm temperate boulder shore
}

\author{
Yoshitake Takada* \\ Ishigaki Tropical Station, Seikai National Fisheries Research Institute, Ishigaki, Okinawa 907-0451, Japan
}

\begin{abstract}
The environment of the habitat is important in the organization of the intertidal community. In a boulder shore habitat, accumulation of boulder layers increases shade and the number of interstices. This study examined whether experimental shade increased the density of mobile animals and modified the community structure at 2 intertidal zones on a moderately sheltered boulder shore in Amakusa, Japan. Artificial shade reduced light intensity and surface temperature of boulders, and subsequently increased microalgal abundance. Mobile animals were sampled quantitatively at 2 zones (high and mid) for 4 treatments: single layer boulders without a roof as a control, double layer boulders without a roof, single layer boulders shaded by a roof for $6 \mathrm{wk}$ and for $2 \mathrm{wk}$. Statistical analyses (MANOVA and ANOVA) showed strong effects of treatments on community diversity and the density of 15 abundant species in both tidal zones. Generally, the diversity was lower in the single layer boulders than the double layer boulders and increased with the experimental shade. Two carnivorous species (Hemigrapsus sanguineus and Japeuthria cingulata) and some herbivorous species (e.g. Nerita japonica and Nipponacmea nigrans) increased in density with the shade, while other herbivores (e.g Monodonta labio and Littorina brevicula) were unaffected. In conclusion, a reduction of environmental stress produced by the shade increased community diversity on the boulder shore, but the responses of mobile animals were species specific. As these responses to a change in the environment occurred within a very short period $(<2 \mathrm{wk})$, migration may play an important role in the short-term variation of community structure on boulder shores.
\end{abstract}

KEY WORDS: Boulder shore - Mobile animals · Community structure - Shade experiment

\section{INTRODUCTION}

Organization of boulder shore communities has received less attention than rocky or sandy shores (see reviews by Underwood \& Chapman 1995, Raffaelli \& Hawkins 1996). Some studies on boulder shores have considered possible factors controlling community structure. The effects of species-area relationships (McGuinness 1984), surface heterogeneity (McGuinness \& Underwood 1986) and rates of disturbance on community structure caused by boulders overturning (Sousa 1979, 1980, McGuinness 1987a,b) have been examined. The accumulation of boulder layers, however, creates a 3-dimensional habitat, and many mobile animals utilize interstices between boulders as

·E-mail: yotak@snf-its.affrc.go.jp well as their surfaces (Takada \& Kikuchi 1991, Chapman \& Underwood 1996).

The importance of habitat structure in organization of intertidal communities is widely recognized (Menge et al. 1985, Hixon \& Menge 1991). On boulder shores, layers of boulders modify the environment and structure of the habitat of mobile animals. During low tide, the top layer of boulders provides the lower layers with shade from direct sunlight, maintaining both lower temperatures and UV illumination. Layers of boulders increase the surface area for attachment of organisms but may decrease the water current and accumulate detritus. Also, small boulder interstices in boulder habitats can provide refuge from large predators. Furthermore, all these factors may interact with each other. This study focuses on whether shade increases the density of animals and affects community structure 
on a boulder shore. In this study, I use 'community' for the set of individual animals which occur together in a boulder shore habitat, regardless of their interactions.

On some boulder shores, secondary habitats, such as algae and barnacles on boulders, can be an important factor influencing community structure (Dean \& Connell 1987a,b, van Tamelen 1987, McGuinness 1988). Thus, boulder shores without secondary habitats are the best locations for examining relationships between refuge from direct sunlight and the community structure of mobile animals. In Amakusa, Japan, the boulder shore has no secondary habitats: mobile animals are abundant and macroscopic sessile organisms are rare in both high and mid intertidal zones (Takada \& Kikuchi 1991).

In this experiment, the physical and biological effects of shade were investigated at 2 tidal levels on a warm temperate boulder shore in Amakusa, Japan. The major aim of this study is to examine the shortterm effects of shade, duration of shade and boulder layers on the community structure of mobile animals.

\section{METHODS}

Study site. Experiments were carried out on a moderately sheltered boulder shore on the eastern side of Magarizaki $\left(32^{\circ} 31^{\prime} \mathrm{N}, 130^{\circ} 02^{\prime} \mathrm{E}\right)$, on the Amakusa Shimoshima Island, west Kyushu, Japan. Average tidal range is $3.3 \mathrm{~m}$ during spring tides. The experimental area $(70 \mathrm{~m}$ along the shore $)$ included a high zone $(2.0 \mathrm{~m}$ above the mean low water of the spring tides) and a mid zone $(0.9 \mathrm{~m})$ which are separated by $25 \mathrm{~m}$. The shore slopes gradually and the sand is covered by cobbles and small boulders (mostly 10 to $20 \mathrm{~cm}$ in long axis within the experimental area and max. $50 \mathrm{~cm}$ outside, hereafter referred to as boulders) 1 or 2 layers deep. These boulders are ovular, weathered chert or rhyolite,

Table 1. Environmental parameters on a typical spring tide day in summer (July 14, 1991) at Magarizaki boulder shore. west Kyushu, Japan

\begin{tabular}{|c|c|c|c|c|}
\hline & \multicolumn{2}{|c|}{ Shade } & \multicolumn{2}{|c|}{ No-shade } \\
\hline Max. illumination (lux) & \multicolumn{2}{|c|}{15000} & \multicolumn{2}{|c|}{89000} \\
\hline Min. humidity (\%) & \multicolumn{2}{|c|}{66.9} & \multicolumn{2}{|c|}{64.7} \\
\hline \multicolumn{5}{|l|}{ Max. temperature $\left({ }^{\circ} \mathrm{C}\right)$} \\
\hline Zone: & High & Mid & High & Mid \\
\hline \multicolumn{5}{|l|}{ Boulder } \\
\hline Top surface & 31.7 & 31.5 & 43.5 & 40.6 \\
\hline Underside & 30.0 & 31.0 & 35.3 & 35.3 \\
\hline 29.4 & & & & \\
\hline Seawater & & & & \\
\hline
\end{tabular}

without pits or cracks on their surface. Almost all the boulders were stable, i.e. remained unmoved on the shore, for the duration of the study. On the surface of the boulders, sedimentation is not obvious and macroscopic sessile organisms are almost absent. The community characteristics in this area are described in detail elsewhere (Takada \& Kikuchi 1990, 1991).

Physical environment. Environmental parameters were measured with and without the artificial shade (see 'Experimental design') every $30 \mathrm{~min}$ from dawn to dusk. These parameters were temperature of boulder surface (non-contact infrared thermometer Horiba, IT330), humidity (Teraoka, TRH-CZ and THP-CZ), and intensity of illumination (digital illuminometer TGK, FLX-1332). The environmental parameters of a typical spring tide day in summer (July 14, 1991) are described in Table 1. Without the shade, maximum temperature on the undersides of the boulders was 5 to $10^{\circ} \mathrm{C}$ lower than the upper surface temperature. Experimental shade reduced the upper surface and the underside temperatures by up to 13 and $7^{\circ} \mathrm{C}$, respectively, when compared to the unshaded area, and the light intensity was reduced to $16.5 \%$.

Chlorophyll concentration. The effect of the shade on microalgal abundance was examined by chlorophyll a concentration on experimental tiles. In June 1991 and 1992, 9 rhyolite rock tiles $\left(100 \mathrm{~cm}^{2}\right)$ were placed horizontally in 2 (with and without shade) treatments, in the 2 (high and mid) zones $(2 \times 9 \times 2 \times 2$ tiles). Seven tiles were lost in the high zone. The artificial shade was exactly the same as in the community experiment and grazers fed naturally on the tiles. After $6 \mathrm{wk}$, the tiles were returned to the laboratory, where chlorophyll was extracted with $90 \%$ ethanol for $24 \mathrm{~h}$ using the polyethylene-bag method (Takada 1993), and chlorophyll a concentrations were measured. Square-root transformed data (Cochran's test for homoscedasticity, $p>0.05$ ) were analyzed using a 3 way ANOVA with year, tidal zone and shade treatment as factors.

Experimental design. Experimental protocol was the same in 1991 and 1992. Experimentally induced shade was used to manipulate physical factors (boulder temperature and intensity of illumination) and biological factors (microalgal abundance on boulders) which were thought to affect community structure of mobile animals on the boulder shore.

The experiment had 4 treatments (Fig. 1): single layers of boulders shaded by a roof for 6 wk (S6); single layers of boulders shaded by a roof for 2 wk (\$2); double layers of boulders without a roof (D); single layers of boulders without a roof as a control (C). Layers of boulders and the organisms remained untouched in all treatments. Seven replicates of each treatment were randomly placed in both the high and mid zones within 
an area of $70 \mathrm{~m}$ along the shore. All replicates were separated by more than $1 \mathrm{~m}$ to avoid influence of shading, and location of replicates differed between years. The treatments were compared to examine the effects of the boulder layers ( $D$ vs $C$ ), addition of the shade ( $\mathrm{S} 6+\mathrm{S} 2$ vs C) and duration of the shade (S6 vs S2)

Artificial shade was provided by 2 layers of mesh roofs $(50 \times 50 \mathrm{~cm})$ positioned approximately $5 \mathrm{~cm}$ above the upper surface of the boulders, and supported by 4 stainless steel legs (Fig. 1). Throughout the experiment, roof treatments were checked every $2 \mathrm{~d}$ and repaired immediately when damaged. Thus, all roof damage was minimized to 1 layer of mesh only. Artificial shade did not appear to alter wave action in the shaded treatments because sedimentation did not change visibly. In the experimental treatment, no boulders were overturned and no macroscopic (>1 mm) sessile organisms were found during the study.

Sampling method. Sampling was done during daytime low tides on July 13 and 14 both in 1991 and 1992. Every quadrat $(40 \times 40 \mathrm{~cm})$ sampled interstitial habitat formed by at least 2 boulders. All animals occurring in the quadrat, except for amphipods and isopods that were too mobile, were counted. Abundant species (mean density $>10 \mathrm{~m}^{-2}$ ) only were examined in detail for species specific effects of treatments. Six abundant species (Monodonta labio, Littorina brevicula, Nerita japonica, Nipponacmea concinna, Hemigrapsus sanguineus and Gaetice depressus) were found in the high zone and 11 species (M. labio, Lunella coronata, Nipponacmea teramachii, Nipponacmea nigrans, Nipponacmea schrenckii, Patelloida pygmaea, Acanthochitona defilippi, Japeuthria cingulata, G. depressus, Pagurus filholi and Polycheira rufescens) were in the mid zone. Of these species, $J$. cingulata is the only carnivorous gastropod. H. sanguineus, G. depressus (Brachyura) and $P$. filholi (Anomura) are omnivores, however $H$. sanguineus has the strongest claws and is the most predatory species. $P$. rufescens is a filter- and deposit-feeding holothurian. The other species are microalgal grazing molluscs.

Statistical analyses. The high and mid zone communities were analyzed separately because the compositions of the species in the community differed. Treatment effects were examined using 4 measures: total number of species, total number of individuals (per $0.16 \mathrm{~m}^{2}$, diversity calculated as the Brillouin index $(H)$, and evenness $(J)$. The 2 indices ( $H$ and $J$ ) were chosen because they are appropriate for small numbers of individuals (Pielou, 1975). These 4 measurements were calculated for each quadrat, analyzed using 2-way ANOVAs (Magurran 1988) with year and treatment effects as factors. When the treatment factor was significant, Scheffe's multiple contrasts, used to examine

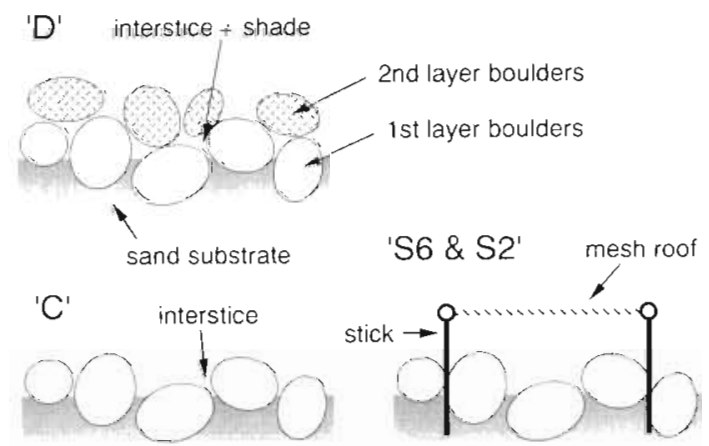

Fig. 1. The structure of boulder layers and the artificial mesh roof used to produce an experimental shade. The experiment had 4 treatments (D, C, S6 and S2)

the means and significance levels of multiple contrasts, were corrected for 3 independent comparisons using the Bonferonni method. Prior to the analysis, the variances were tested for homogeneity using Cochran's test $(\mathrm{p}>0.05)$.

Density of abundant species (per $0.16 \mathrm{~m}^{2}$ ) was analyzed using a 2-factor (treatment and year) multivariate analysis of variance (MANOVA) using Wilks' Lambda (Super ANOVA, Abacus) on $\log (x+1)$ transformed data. When the result of MANOVA was significant, 2-way ANOVA and Scheffe's multiple contrasts (with Bonferonni correction) were applied for each species. Homogeneity of variances was confirmed by a test recommended by Johnson \& Field (1993) and Cochran's test $(p>0.05)$.

\section{RESULTS}

\section{Chlorophyll concentration}

Abundance of microalgae, the major food resource for grazers, was assessed using chlorophyll a concentrations (Fig. 2). Abundance of microalgae was significantly higher in the mid zone than in the high zone, and increased significantly in the shade treatment (Table 2). It showed that the food abundance for grazers increased in the shade treatments of the experiment. However, these patterns varied among years and the difference in microalgae between tidal zones was larger in the first year than in the second year (year $\times$ height interaction in Table 2, Fig. 2).

\section{Shade experiments}

With the exception of the evenness $(J)$ in the mid zone, variation among treatments in the measurements 


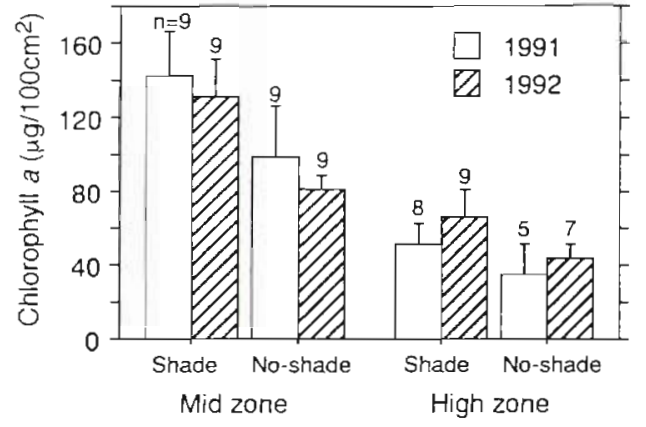

Fig. 2. Mean abundance $( \pm \mathrm{SD})$ of microalgae assessed using concentrations of chlorophyll $a$ on the rhyolite tiles $\left(100 \mathrm{~cm}^{2}\right)$.

The number of tiles examined is given above each column

of communities in both zones was consistent between years (Table 3 , all year $\times$ treatment are not significant). Annual variation occurred in the number of individuals in the high zone and evenness in the high and mid zones. Multiple contrast showed that a second layer of boulders or shade increased most of the measurements of community structure at both zones. But the duration of the shade (S2 vs S6) did not affect the community structure. In general, the double boulder layer unshaded treatment (D) contained the most complex community (i.e. higher number of species, number of individuals and diversity), followed by the 2 experimentally shaded treatments (S6 and S2), while the single boulder layer unshaded treatment (C) had the least complex community.

Community structure of the abundant species varied significantly between years and among treatments in both the high and mid zones (MANOVA, Table 4) and the effects of the treatments did not vary between years (Table 4, year $\times$ treatment, not significant).

Patterns of density of abundant species varied among treatments and between years. In all 6 abundant species in the high zone, the effects of treatments did not vary between years (Fig. 3, Table 5, year $x$

Table 2. Three-way ANOVA to investigate chlorophyll a concentrations with or without the artificial shade at 2 tidal heights for 2 years. Data were square-root transformed before the analysis

\begin{tabular}{|lrrrc|}
\hline Factors & df & MS & $F$ & $p$ \\
\hline Year & 1 & 0.281 & 0.276 & 0.601 \\
Height & 1 & 208.684 & 204.713 & $<0.0001$ \\
Shade & 1 & 54.392 & 53.357 & $<0.0001$ \\
$\mathrm{Y} \times \mathrm{H}$ & 1 & 9.475 & 9.295 & 0.004 \\
$\mathrm{Y} \times \mathrm{S}$ & 1 & 0.246 & 0.241 & 0.625 \\
$\mathrm{H} \times \mathrm{S}$ & 1 & 2.270 & 2.227 & 0.141 \\
$\mathrm{Y} \times \mathrm{H} \times \mathrm{S}$ & 1 & 0.038 & 0.037 & 0.848 \\
Error & 57 & 1.019 & & \\
\hline
\end{tabular}

treatment, not significant). Treatments affected the density of 5 species (Monodonta labio, Littorina brevicula, Nerita japonica, Nipponacmea concinna and Hemigrapsus sanguineus). Annual variations in the density occurred in 3 species: $M$. labio, $H$. sanguineus and Gaetice depressus. Multiple contrast showed that densities of the 5 species (except for $G$. depressus) in the double boulder layer unshaded treatment (D) were significantly higher than those in the single boulder layer unshaded treatment (C). The shade (S2 + S6 vs C) significantly increased the density of $N$. japonica, N. concinna and H. sanguineus in 1991. H. sanguineus in 1992 was almost significant $(p=0.0172)$. Thus, the double boulder layers in the high zone increased the density of the abundant species more than the shade.

Similarly to in the high zone, the effects of treatments in the mid zone did not vary between years (Fig. 4 , Table 5). The density of 6 out of 11 species varied among treatments and the density of 4 species varied between years. The double boulder layers increased the density of Nipponacmea teramachii, N. nigrans, Japeuthria cingulata, Pagurus filholi, Polycheira rufescens and Monodonta labio in 1992 (Table 5, D vs C). The effect of artificial shade (S2 + S6 vs C) on these species was significant in all cases except for $M$. labio and $P$. rufescens. The shade provided a more suitable habitat for $P$, filholi than an additional layer of boulders, because the mean density of $P$. filholi in the shaded treatments (S6 and S2) was higher than in the double boulder layer unshaded treatment (D) (Fig. 4).

Densities of some omnivores (Hemigrapsus sanguineus and Pagurus filholi), the carnivore Japeuthria cingulata and the most abundant herbivore in the mid zone (Nipponacmea teramachii) increased in the shaded treatments. Other species, Monodonta labio and Gaetice depressus, which occurred in both high and mid zones, however, did not respond to the shade. With the exception of $P$. filholl, all of the species with significant treatment effects had higher densities in the double boulder layer unshaded treatment. In both zones, densities of all abundant species did not vary significantly in relation to the duration of shade (S2 vs S6), which suggests that the response to the shade occurred within 2 wk and then remained apparently stable.

\section{DISCUSSION}

In both zones, the double boulder layers and the experimental addition of shade affected the diversity indices and the density of some species in the treatments, and these effects did not vary between years. No effects of the duration of shade were observed. 


\section{Community diversity}

Similar to other studies (McGuinness \& Underwood 1986, Dean \& Connell 1987a, Menge \& Sutherland 1987), the increase in habitat complexity provided by the double boulder layers and the decrease in environmental stress provided by the shade treatments increased diversity of mobile animals on this boulder shore. The results of this study, however, also demonstrated that the community responded to the decrease in environmental stress within $2 \mathrm{wk}$.

The general response to the experimental treatments was similar in both zones, despite a difference in the species composition between communities in the high and mid zones. In the mid zone, however, more species were unaffected by the experimental treatments (5 species out of 11) than in the high zone (1 out of 6$)$. Interestingly, the 2 species (Monodonta labio and Gaetice depressus) that occurred in both zones did not respond to the reduced environmental stress at either zone.

\section{Effects of boulder layers}

The abundant species showed species specific responses to the boulder layers and the artificial shade. Generally, the double boulder layer unshaded treatment (D) supported a greater density of animals than the single layer unshaded treatment (C), however no significant differences were detected for Gaetice depressus in either zone, or for Lunella coronata, Nipponacmea schrenckii, Patelloida pygmaea and Acanthochitona defilippi in the mid zone. $G$. depressus is a highly mobile crab which digs transient holes under boulders (Takada pers. obs.) that are utilized as refuges from physical stress during low tides. L. coronata and $A$. defilippi sometimes attach to the under surface of the lower layer of boulders, partially burying their body in the sandy sediments (Wada et al. 1983, Takada pers. obs.). Thus, the ability to create refuges may explain the lack of treatment effects on the density of these 3 species. In contrast, species that are unable to make their own refuge appear to be more sensitive to the number of boulder layers, because they provide protection from physical stress.

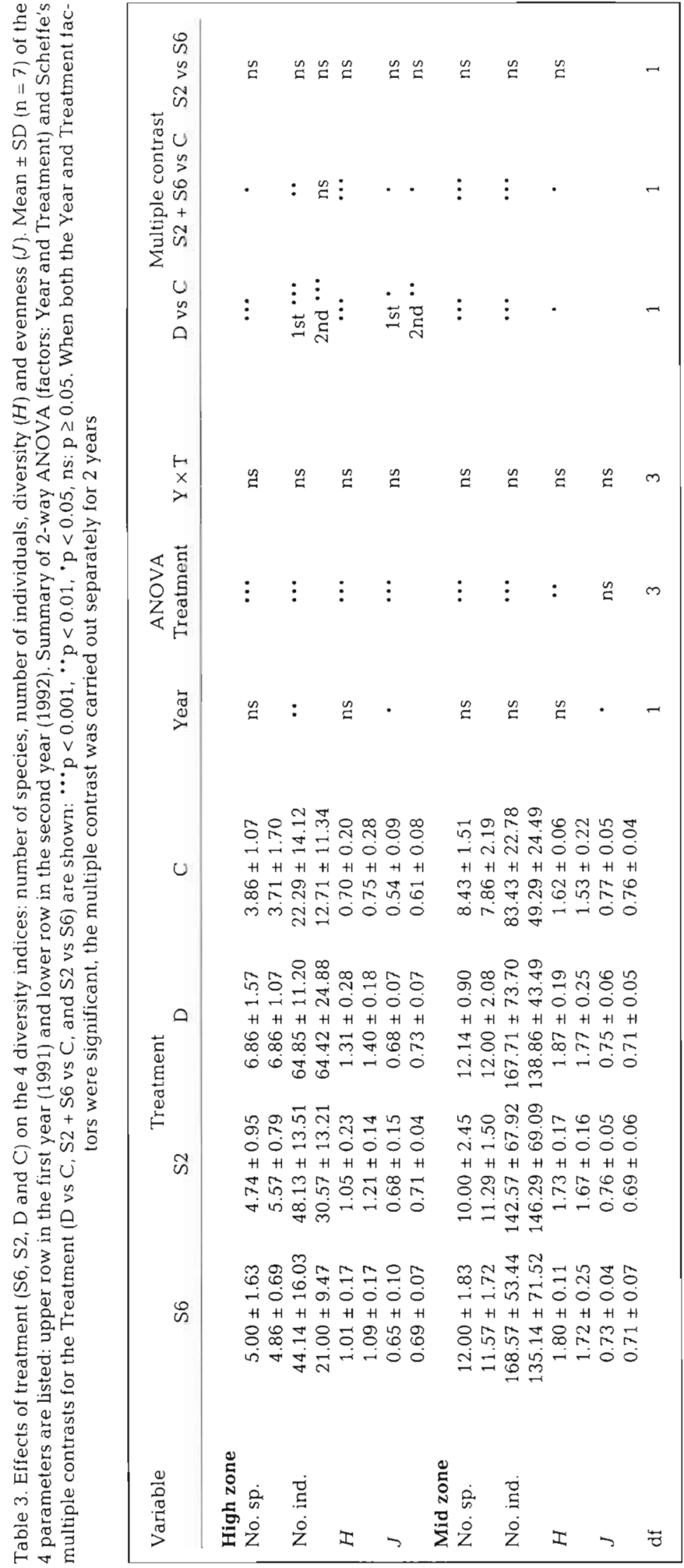


Table 4. Two-way MANOVA to investigate animal densities of the 4 treatments for the 2 years

\begin{tabular}{|c|c|c|c|c|}
\hline Factors & df & Wilks' $\Lambda$ & $F$ & $\mathrm{p}$ \\
\hline \multicolumn{5}{|c|}{ High zone ( 6 species) } \\
\hline Year & 1,48 & 0.277 & 18.67 & 0.0001 \\
\hline Treatment & 3,48 & 0.191 & 5.393 & 0.0001 \\
\hline$Y \times T$ & 3,48 & 0.597 & 1.357 & 0.166 \\
\hline \multicolumn{5}{|c|}{ Mid zone (11 species) } \\
\hline Year & 1,48 & 0.376 & 5.728 & 0.0001 \\
\hline Treatment & 3,48 & 0.165 & 2.878 & 0.0001 \\
\hline$Y \times T$ & 3,48 & 0.496 & 0.918 & 0.599 \\
\hline
\end{tabular}

An artifact of the double boulder layer treatment was an increase in surface area which was not measured in this study. Differences between the double boulder layer unshaded treatment (D) and the single boulder layer shaded treatments (S6 and S2) indicate an effect of surface area. Increased surface area provides more habitat for grazer molluscs to attach and thus may

\section{High Zone}

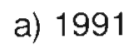

b) 1992

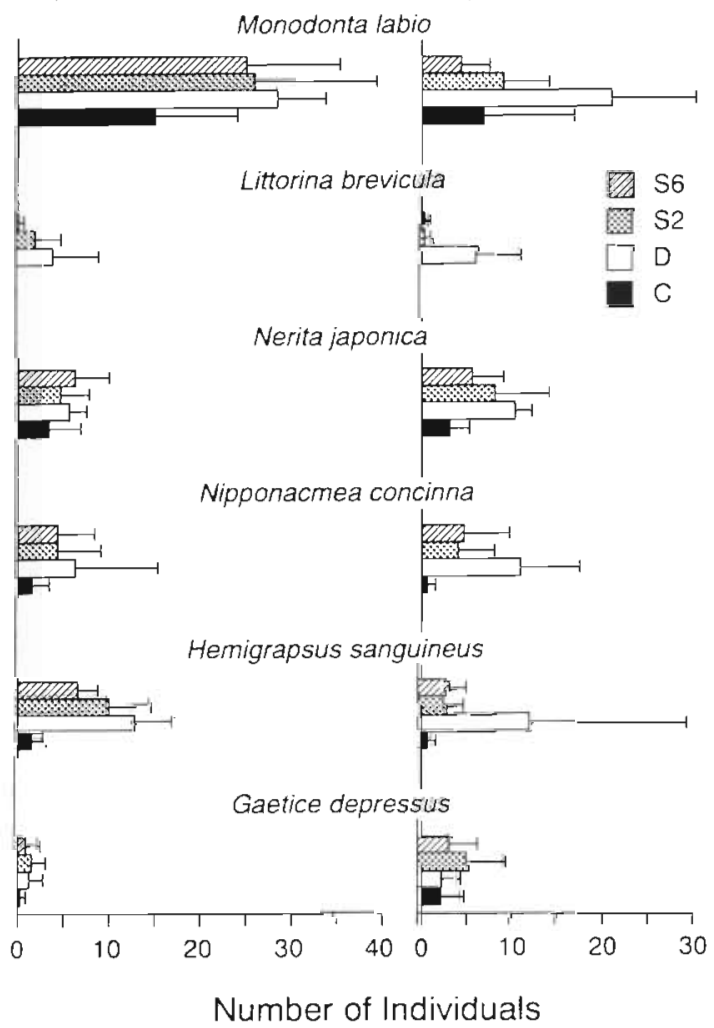

Fig. 3. Abundance (mean $\pm \mathrm{SD}, \mathrm{n}=7$ ) of the 6 species (per $0.16 \mathrm{~m}^{2}$ ) in the high zone in (a) 1991 and (b) 1992 of the 4 treatments; S6: experimentally shaded for $6 \mathrm{wk}$, S2: experimentally shaded for $2 \mathrm{wk}, \mathrm{D}$ : double layers of boulders without shade, $\mathrm{C}$ : single layer of boulders without shade explain the increased densities of Monodonta labio and Littorina brevicula. This effect, however, was not general for all grazers because other species (Lunella coronata, Nipponacmea schrenckii, Patelloida pygmaea and Acanthochitona defilippi) were not affected. An increase in surface area could not explain the increase in the deposit feeder Polycheira rufescens, which utilizes interstices of boulders. Double boulder layers may reduce the flow of water and predation by large predators.

\section{Effects of artificial shade}

Artificial shade significantly increased the density of 2 carnivorous species, Hemigrapsus sanguineus in the high zone and Japeuthria cingulata in the mid zone.

\section{Mid Zone}
a) 1991
b) 1992

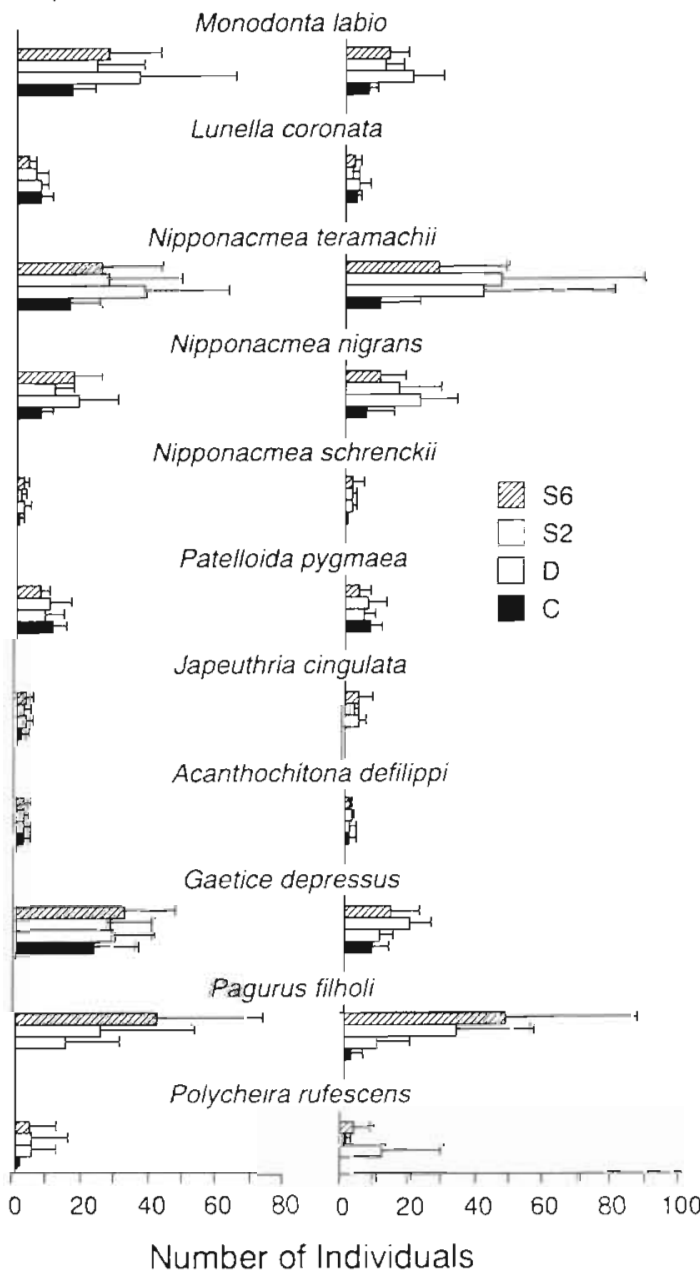

Fig. 4. Abundance (mean $\pm \mathrm{SD}, \mathrm{n}=7$ ) of the 11 species (per $0.16 \mathrm{~m}^{2}$ ) in the mid zone in (a) 1991 and (b) 1992 
Table 5. Results of 2-way ANOVAs for each animal species and Scheffe's multiple contrasts for the Treatment (D vs C, S2 + S6 vs C, and S2 vs S6). Significance levels are: $\cdots p<0.001, \cdots p<0.01, \cdot p<0.05$, ns: $p \geq 0.05$. When both the Year and Treatment factors were significant, the multiple contrast was done separately for each year. Data were log $(x+1)$ transformed before the analysis

\begin{tabular}{|c|c|c|c|c|c|c|}
\hline Species & Year & $\begin{array}{l}\text { Factors } \\
\text { Treatment }\end{array}$ & $\mathrm{Y} \times \mathrm{T}$ & D vs C & $\begin{array}{l}\text { Multiple contras } \\
\mathrm{S} 2+\mathrm{S} 6 \text { vs } \mathrm{C}\end{array}$ & S2 vs S6 \\
\hline \multicolumn{7}{|l|}{ High zone } \\
\hline \multirow[t]{2}{*}{ Monodonta labio } & $\cdots$ & $\cdots$ & ns & $1 \mathrm{st} \cdot$ & ns & ns \\
\hline & & & & 2nd $\cdots$ & ns & ns \\
\hline Littorina brevicula & ns & $\cdots$ & ns & $\cdots$ & ns & ns \\
\hline Nerita japonica & ns & .. & ns & 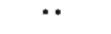 & • & ns \\
\hline Nipponacmea concinna & ns & $\cdot \cdot$ & ns & $\cdots$ & $\cdot$ & ns \\
\hline \multirow[t]{2}{*}{ Hemigrapsus sanguineus } & $\cdots$ & $\cdots$ & ns & 1 st $\cdots$ & $\cdots$ & ns \\
\hline & & & & $2 n d \cdots$ & ns & ns \\
\hline Gaetice depressus & $\cdots$ & ns & ns & & & \\
\hline \multicolumn{7}{|l|}{ Mid zone } \\
\hline \multirow[t]{2}{*}{ Monodonta labio } & $\because$ & .. & ns & 1 st ns & ns & $\mathrm{ns}$ \\
\hline & & & & 2nd $\cdots$ & ns & ns \\
\hline Lunella coronata & $\cdots$ & ns & ns & & & \\
\hline Nipponacmea teramachii & ns & $\cdot$ & ns & $\cdot$ & $\cdot$ & ns \\
\hline Nipponacmea nigrans & ns & $\because$ & ns & $\cdots$ & - & ns \\
\hline Nipponacmea schrenckü & ns & ns & ns & & & \\
\hline Patelloida pygmaea & $\cdot$ & ns & ns & & & \\
\hline Acanthochitona defilippi & ns & ns & ns & & & \\
\hline Japeuthria cingulata & ns & $\cdots$ & ns & $\because$ & $\cdots$ & ns \\
\hline Gaetice depressus & $\cdots$ & ns & ns & & & \\
\hline Pagurus filholi & ns & $\cdots$ & ns & 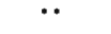 & $\cdots$ & ns \\
\hline Polycheira rufescens & ns & $\cdot \cdot$ & ns & $\cdots$ & ns & ns \\
\hline $\mathrm{df}$ & 1 & 3 & 3 & 1 & 1 & 1 \\
\hline
\end{tabular}

These highly mobile species may utilize the shaded area as a refuge during low tide and forage during the awash and/or high tide period. Similar increases of intertidal carnivores in areas of reduced environmental stress have been observed on rocky-platform shores (Menge 1978, Moran 1985).

In addition to reducing environmental stress, the experimental shade increased microalgal abundance by reducing light intensity and temperature. Despite an increase in food, artificial shade produced a variety of responses in the microalgal grazers. While some grazer species (e.g. Monodonta labio and Littorina brevicula) were not affected by shade, others (e.g. Nerita japonica and Nipponacmea nigrans) increased in density, responding quickly to reduced environmental stress. The short duration of the experiment or the quality of artificial shade provided may explain the lack of response in the other species. Increases in density of herbivores corresponding with increases in available refuges has also been observed on temperate (Raffaelli \& Hughes 1978) and tropical (Menge \& Lubchenco 1981, Menge et al. 1983) rocky shores. McGuinness \& Underwood (1986) observed that an increase in surface complexity (pits and grooves) increased grazer density on boulders during a long-term experiment (from 3 mo to $1 \mathrm{yr}$ ). This study, however, found that grazers responded to the artificial shade within a short period ( 2 wk). As herbivores are known to seek appropriate refuge after foraging (Garrity 1984, Williams \& Morritt 1995), refuge-seeking migration of grazers may have caused this rapid response to artificiāl shade.

\section{Mechanisms for short-term responses}

Recruitment, mortality and migration are key mechanisms for short-term fluctuations of density. Differential recruitment between the experimental treatments does not explain the results because the experiment was done outside the recruitment seasons of several abundant species: Monodonta labio (Takada 1996), Lunella coronata (Yukihira et al. 1995). Nipponacmea limpets (Takada 1997), Littorina brevicula (Takada 1992), Polycheira rufescens (Wada 1992), and Hemigrapsus sanguineus and Gaetice depressus (Fukui 1988). Small individuals of other species were absent (Patelloida pygmaea and Japeuthria cingulata) or very rare (Nerita japonica). One abundant species, Pagurus filholi, recruits during summer and many small individuals were sampled in this study (Takada unpubl.).

Mortality, by either physical stress or predation, did not appear to be important in this short-term experiment. Changes in the density of the animals between periods of shade indicate that artificial shade could have altered mortality rates, but this did not occur. Predation may be 
internal (i.e. by a member of this community, such as Hemigrapsus sanguineus or Japeuthria cingulata) or external (i.e. by subtidal predators during low tides). Although predators within the community increased in density in the shaded treatment, there was no evidence of corresponding declines in prey numbers.

In other experiments, molluscan grazers, predators or both migrated into roof treatments for refuge (Menge 1976, Underwood 1980, Williams 1994). In the present study, individuals migrated to the shaded treatments within the first $2 \mathrm{wk}$ and in the following month the community appeared to stabilize. Individuals used the shaded area either as a permanent habitat or a temporal refuge during daytime or low tide. In either case, migration appears to be the most likely mechanism controlling the density of most species, except for Pagurus filholi, for which recruitment played some role.

The several models that have been proposed to explain intertidal community structure (Sousa 1979, McGuinness 1987b, Menge \& Sutherland 1987) are concerned mainly with sessile organisms that require long periods to colonize, and do not apply to mobile animals directly. Mobile animals can react to relatively short-term changes of environmental stress and can use shaded areas as a temporal refuge. Hixon \& Menge (1991) predicted a complex response among communities of mobile animals, if effects of predation, competition and habitat complexity are compounded. The results of this study suggest that the 3 -dimensional structure of the double boulder layers alters community structure, but effects of habitat complexity were beyond the scope of this study.

In conclusion, reduced environmental stress by artificial shade increased community diversity and density of some of the abundant mobile animals on a boulder shore. The response to the artificial shade occurred within a short period $(<2 \mathrm{wk})$, which suggested that migration may be an important colonizing mechanism in the structure of these communities. Future studies need to separate the effects of shade and structural complexity created by boulder layers to improve our understanding of these boulder shore communities.

Acknowledgements. I thank Prof. T. Kikuchi for giving me the opportunity to study this subject. Summer course students of Kyushu University in 1991 and 1992 helped with some of the fieldwork. Drs Y. Kurihara, S. Nishihama, J. St John and G. A. Williams made helpful comments on the manuscript.

\section{LITERATURE CITED}

Chapman MG. Underwood AJ (1996) Experiments on effects of sampling biota under intertidal and shallow subtidal boulders. J Exp Mar Biol Ecol 207:103-126

Dean RL, Connell JH (1987a) Marine invertebrates in an algal succession. II. Tests of hypotheses to explain changes in di- versity with succession. J Exp Mar Biol Ecol 109:217-247

Dean RL, Connell JH (1987b) Marine invertebrates in an algal succession. III. Mechanisms linking habitat complexity with diversity. J Exp Mar Biol Ecol. 109:249-273

Fukui Y (1988) Comparative studies on the life history of the grapsid crabs (Crustacea, Brachyura) inhabiting intertidal cobble and boulder shores. Publ Seto Mar Biol Lab Kyoto Univ (Jpn) 33:121-162

Garrity SD (1984) Some adaptations of gastropods to physical stress on a tropical rocky shore. Ecology 65:559-574

Hixon MA, Menge BA (1991) Species diversity: prey refuges modify the interactive effects of predation and competition. Theor Popul Biol 39:178-200

Johnson CR, Field CA (1993) Using fixed-effects model multivariate analysis of variance in marine biology and ecology. Oceanogr Mar Biol Annu Rev 31:177-221

Magurran AE (1988) Ecological diversity and its measurement. Princeton University Press, Princeton, NJ

McGuinness KA (1984) Species-area relations of communities on intertidal boulders: testing the null hypothesis. J Biogeogr 11:439-456

McGuinness KA (1987a) Disturbance and organisms on boul.ders. I. Patterns in the environment and the community. Oecologia 71:409-419

McGuinness KA (1987b) Disturbance and organisms on boulders. II. Causes of patterns in diversity and abundance. Oecologia 71:420-430

McGuinness KA (1988) Short-term effects of sessile organisms on colonization of intertidal boulders. J Exp Mar Biol Ecol 116:159-175

McGuinness KA, Underwood AJ (1986) Habitat structure and the nature of communities on intertidal boulders. J Exp Mar Biol Ecol 104:97-123

Menge BA (1976) Organization of the New England rocky intertidal community: role of predation, competition, and environmental heterogeneity. Ecol Monogr 46:355-393

Menge BA (1978) Predation intensity in a rocky intertidal community: relation between predator foraging activity and environmental harshness. Oecologia 34:1-16

Menge BA, Lubchenco $J$ (1981) Community organization in temperate and tropical rocky intertidal habitats: prey refuges in relation to consumer pressure gradients. Ecol Monogr 51:429-450

Menge BA, Sutherland JP (1987) Community regulation: variation in disturbance, competition, and predation in relation to environmental stress and recruitment. Am Nat 130:730-757

Menge BA, Ashkenas LR, Maston A (1983) Use of artificial holes in studying community development in cryptic marine habitats in a tropical rocky intertidal region. Mar Biol 77:129-142

Menge BA, Lubchenco J, Ashkenas LR (1985) Diversity, heterogeneity and consumer pressure in a tropical rocky intertidal community. Oecologia 65:394-405

Moran MJ (1985) Distribution and dispersion of the predatory intertidal gastropod Moroula marginalba. Mar Ecol Prog Ser 22:41-52

Pielou EC (1975) Ecological diversity. Wiley-Interscience, New York

Raffaelli D, Hawkins S (1996) Intertidal ecology. Chapman \& Hall, London

Raffaelli D. Hughes RN (1978) The eftects of crevice size and availability on populations of Littorina rudis and Littorina neritoides. J Anim Ecol 47:71-83

Sousa WP (1979) Disturbance in marine intertidal boulder fields: the nonequilibrium maintenance of species diversity. Ecology 60:1225-1239

Sousa WP (1980) The responses of a community to distur- 
bance: the importance of successional age and species' life histories. Oecologia 45:72-81

Takada Y (1992) The migration and growth of Littorina brevicula on a boulder shore in Amakusa, Japan. In: Grahame J, Mill PJ, Reid DG (eds) Proceedings of the third international symposium on littorinid biology. The Malacological Society of London, London, p 277-279

Takada Y (1993) Evaluation of methods for chlorophyll estimation of littoral epilithic microalgae. Benthos Res (Jpn) 44:45-55 (in Japanese with English abstract)

Takada Y (1996) Seasonal and vertical variations in size structure and recruitment of the intertidal gastropod, Monodonta labio. Venus Jpn J Malacol 55:105-113

Takada Y (1997) Recruitment, growth and survival of Nipponacmea limpets on a boulder shore in Amakusa. Venus Jpn J Malacol 56:145-155

Takada Y, Kikuchi T (1990) Mobile molluscan communities in boulder shores and the comparison with other intertidal habitats in Amakusa. Publ Amakusa Mar Biol Lab Kyushu Univ 10:145-168

Takada Y, Kikuchi T (1991) Seasonal and vertical variation of the boulder shore fauna in Amakusa. Publ Amakusa Mar Biol Lab Kyushu Univ 11:1-17

Underwood AJ (1980) The effects of grazing by gastropods and physical factors on the upper limits of distribution of intertidal macroalgae. Oecologia 46:201-213

Editorial responsibility: Otto Kinne (Editor), Oldendorf/Luhe, Germany
Underwood AJ, Chapman MG (eds) (1995) Coastal marine ecology of temperate Australia. University of New South Wales Press, Sydney

van Tamelen PG (1987) Early successional mechanisms in the rocky intertidal: the role of direct and indirect interactions. J Exp Mar Biol Ecol 112:39-48

Wada K (1992) Temporal change in density and size structure of the sea cucumber Polycheira rufescens inhabiting the intertidal boulder beach at Hatakejima Island, Tanabe bay, central Japan. Publ Seto Mar Biol Lab Kyoto Univ (Jpn) 35:363-370

Wada K, Fukui Y, Abe N (1983) Distribution of motile animals in a boulder shore. Benthos Res (Jpn) 25:33-38 (in Japanese with English abstract)

Williams GA (1994) The relationship between shade and molluscan grazing in structuring communities on a moderately-exposed tropical rocky shore. J Exp Mar Biol Ecol 178:79-95

Williams GA, Morritt D (1995) Habitat partitioning and thermal tolerance in a tropical limpet, Cellana grata. Mar Ecol Prog Ser 124:89-103

Yukihira H, Noda M, Hashimoto H, Gushima K (1995) On the maturation and spawning on moon coronate turban. Lunella coronata coreensis (Recluz, 1853). J Fac Appl Biol Sci Hiroshima Univ (Jpn) 34:133-145 (in Japanese with English abstract)

Submitted: January 22, 1999; Accepted: June 22, 1999

Proofs received from author(s): November 1, 1999 